\title{
Flow Cytometric Analysis of the Cell Cycle of the Leukemic Gell Lines Treated with Etoposide and Cytosine Arabinoside
}

\author{
Kiyoshi Ishiyama, Shinji Satoh, Yoshiharu Igarashi, \\ Hiroaki Kumagai, Akito Yahagi and Hideo Sasaki \\ The Third Department of Internal Medicine, Yamagata \\ University School of Medicine, Yamagata 990-23
}

\begin{abstract}
Ishiyama, K., Satoh, S., Igarashi, Y., Kumagai, H., Yahagi, A. and Sasaki, H. Flow Cytometric Analysis of the Cell Cycle of the Leukemic Cell Lines Treated with Etoposide and Cytosine Arabinoside. Tohoku J. Exp. Med., 1994, 174 (2), 95-107 — Effects of etoposide (VP-16) and cytosine arabinoside (Ara-C) on the cell cycle of HL-60 and THP-1 cells were studied by flow cytometry using the bromodeoxyuridine (BrdU)/DNA assay technique to investigate the efficacy of VP-16 for monocytic leukemia cells. VP-16 inhibited the proliferation of THP-1 cells more strongly than that of HL- 60 cells at any concentrations used at 24 and $48 \mathrm{hr}$. VP-16 arrested HL-60 and THP-1 cells in the $\mathrm{G}_{2} / \mathrm{M}$ phase and reduced them in the $G_{0} / G_{1}$ and early $S$ phase at higher concentrations. There was no significant difference in the percentage of $G_{2} / M$ phase cells at the same concentration between both cells. However, reduction in the $\mathrm{G}_{0} / \mathrm{G}_{1}$ and early $\mathrm{S}$ phase cells was more marked in THP-1 than HL-60 cells significantly. On the other hand, Ara-C perturbed the cell cycle of HL-60 cells more than that of THP-1 cells at 24 and $48 \mathrm{hr}$. These results suggest that the effects of VP-16 on the cell cycle may be more intense in THP-1 than HL-60 cells, and support the efficacy of VP-16 for treating monocytic leukemia in vivo.— flow cytometry; cell cycle; bromodeoxyuridine (BrdU); etoposide (VP-16); cytosine arabinoside (Ara-C)
\end{abstract}

Etoposide (VP-16), a newly developed semisynthetic derivative of podophyllotoxin (Loike and Horwitz 1976; Roberts et al. 1980), is recently available for the treatment of acute leukemias and malignant lymphomas, and has been found useful for relapsed or refractory cases (Mathé et al. 1974; Bishop et al. 1990). This drug is considered more effective for patients with monocytic leukemia than for those with other types of leukemia (Mathé et al. 1974; Bernasconi et al. 1982;

Received March 30, 1994; revision accepted for publication August 11, 1994.

Address for reprints: Kiyoshi Ishiyama, M.D., Ph.D., Third Department of Internal Medicine, Yamagata University School of Medicine, 2-2-2 Iida-Nishi, Yamagata, 990-23, Japan.

Abbreviations used in this paper: BrdU, bromodeoxyuridine; PI, propidium iodide; DNA, deoxyribonucleic acid; Ara-C, cytosine arabinoside; AMoL, acute monocytic leukemia; APL, acute promyelocytic leukemia; FCS, fetal calf serum; PBS, phosphate-buffered saline; FITC, fluorescein isothiocyanate; s.E., standard error. 
Varini and Cavalli 1982; Odom and Gordon 1984; Moriyama et al. 1985). However, its efficacy for monocytic leukemia cells has yet to be determined.

VP-16 causes $\mathrm{G}_{2}$ block in the cell cycle by flow cytometric analysis using propidium iodide (PI) staining (Krishan et al. 1975). A new method for flow cytometric analysis of the cell cycle using the anti-bromodeoxyuridine (BrdU) monoclonal antibody, which was previously created (Gratzner 1982), and PI staining was developed (Dolbeare et al. 1983). This method needs no special facilities nor special technical skills like other methods using radioisotopes and has been applied to many clinical studies on the cell cycle (Katano et al. 1989; Tafuri and Andreeff 1990; Bettelheim et al. 1991). So we studied effects of antileukemic agents on the cell cycle of leukemic cells using this method to investigate the efficacy of VP-16 for monocytic leukemia cells in vitro.

In this study, we used two human leukemic cell lines, THP-1 cells, a human leukemic cell line derived from the peripheral blood of a patient with acute monocytic leukemia (AMoL) (Tsuchiya et al. 1980), and HL-60 cells, a human leukemic cell line derived from the peripheral blood of a patient with acute promyelocytic leukemia (APL) (Collins et al. 1977). The effects of VP-16 on the cell cycle of both cells were examined by flow cytometric analysis using the anti-BrdU monoclonal antibody/PI assay technique and compared between both of the cells to find that this method could detect the efficacy of VP-16 for monocytic leukemia cells in vitro. The effects of cytosine arabinoside (Ara-C) on the cell cycle of both cells were also examined and compared with those of VP-16.

\section{Materials and Methods}

Antileukemic agents. VP-16 was kindly provided by Nippon Kayaku Co., Ltd. (Tokyo) and Ara-C, by Nippon Shinyaku Co., Ltd. (Tokyo).

Cell culture. HL-60 cells were kindly provided by Dr F. Sendo (Department of Parasitology and Immunology, Yamagata University, Yamagata) and THP-1 cells, by Dr S. Yokoyama (Department of Pediatrics, Yamagata University, Yamagata). HL-60 and THP-1 cells were grown in RPMI 1640 medium (Nissui Pharmaceutical Co., Ltd., Tokyo) containing 10\% fetal calf serum (FCS) (Bioproducts, Inc., Walkersville, MD, USA) in a humidified atmosphere of $95 \%$ air and $5 \% \mathrm{CO}_{2}$ at $37^{\circ} \mathrm{C}$ and maintained by dilution with fresh medium twice weekly.

Exponetially growing HL-60 and/or THP-1 cells were suspended in $10 \mathrm{ml}$ of RPMI 1640 medium containing $10 \%$ FCS at a density of $2 \times 10^{5}$ cells $/ \mathrm{ml}$ in $25-\mathrm{cm}^{2}$ tissue culture flasks (Sumilon, Sumitomo Bakelite Co., Ltd., Tokyo) and incubated with or without antileukemic agents (VP-16 or Ara-C) at various concentrations for 24 or $48 \mathrm{hr}$. Viable cells were counted by the trypan blue dye exclusion method at the end of culture.

Staining. Staining procedure was performed according to the modified method which was reported previously (Dolbeare et al. 1983). Briefly, BrdU (Sigma Chemical Co., St. Louis, MO, USA) was added to the medium at a final 
concentration of $5 \mu \mathrm{g} / \mathrm{ml} 30 \mathrm{~min}$ before the end of culture. The cells were harvested and washed twice with cold phosphate-buffered saline (PBS) by centrifugation at $4^{\circ} \mathrm{C}$ and fixed with $2 \mathrm{ml}$ of $70 \%$ ethanol for more than $30 \mathrm{~min}$. DNA of ethanol-fixed cells $\left(2 \times 10^{6}\right.$ cells) was partially denaturated by exposure to $1 \mathrm{ml}$ of $4 \mathrm{~N} \mathrm{HCl}$ at room temperature for $20 \mathrm{~min}$. The cells were neutralized by $0.1 \mathrm{M}$ sodium tetraborate $\left(\mathrm{Na}_{2} \mathrm{~B}_{4} \mathrm{O}_{7}\right)$ (Wako Chemical Co., Ltd., Osaka), washed with PBS and resuspended in $50 \mu \mathrm{l}$ of PBS containing $0.5 \%$ Tween 20 (Serva Co., Heidelberg, NY, USA). The cells were then incubated with fluorescein isothiocyanate (FITC)-conjugated anti-BrdU monoclonal antibody (Becton-Dickinson Co., Ltd., San Jose, CA, USA) in the dark at room temperature for $30 \mathrm{~min}$. The cells were washed twice with PBS by centrifugation and resuspended in PBS. Cellular double-stranded DNA was stained with PI (Sigma Chemical Co.) at 50 $\mu \mathrm{g} / \mathrm{ml}$ for $15 \mathrm{~min}$. Clumps of cells were then removed by filtration through $50-\mu \mathrm{m}$ nylon mesh and the filtered cells were analyzed by a flow cytometer.

Flow cytometry. The stained cells were analyzed by a flow cytometer, FACStar (Becton-Dickinson Co., Ltd.). The excitation wavelength was $488 \mathrm{~nm}$ and the fluorescent wavelengths of FITC and PI were 530 and $575 \mathrm{~nm}$, respectively. Routinely, 10,000 cells were measured for each distribution at a flow rate of less than 300 cells/sec. Bivariate BrdU/DNA distribution $(64 \times 64$ channel $)$ was obtained by software Consort 30 program (Becton-Dickinson Co.). Fig. 1 shows the bivariate BrdU/DNA distribution of exponentially growing HL-60 cells. It was plotted as a contour graph by the cell number of each channel. Windows for

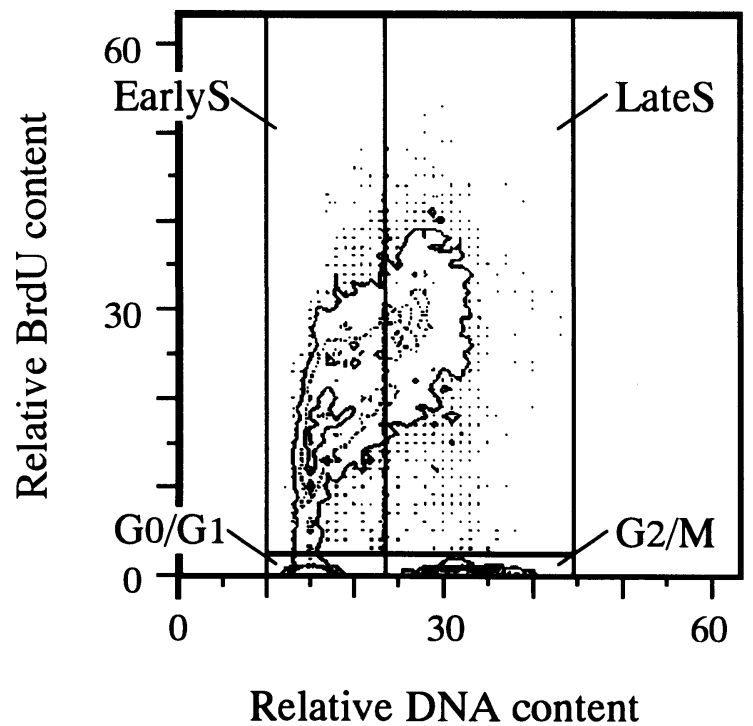

Fig. 1. Bivariate BrdU/DNA distribution of exponentially growing HL-60 cells. Distribution is shown for untreated control cells. Four windows indicate phases of the cell cycle. 
the cells in each phase of the cell cycle were set as indicated in Fig. 1. Cells with low DNA content and low BrdU incorporation were defined as those in the $G_{0} / G_{1}$ phase, cells with twice the DNA content and low BrdU incorporation as in the $\mathrm{G}_{2}$ / $\mathrm{M}$ phase and those with high BrdU incorporation as in the $\mathrm{S}$ phase. The $\mathrm{S}$ phase was divided into early and late $S$ subphases by the division line between $G_{0} / G_{1}$ and $\mathrm{G}_{2} / \mathrm{M}$ phases.

Statistics. Results were expressed as the means \pm s.E. All $p$ values were obtained by the non-paired $t$ test.
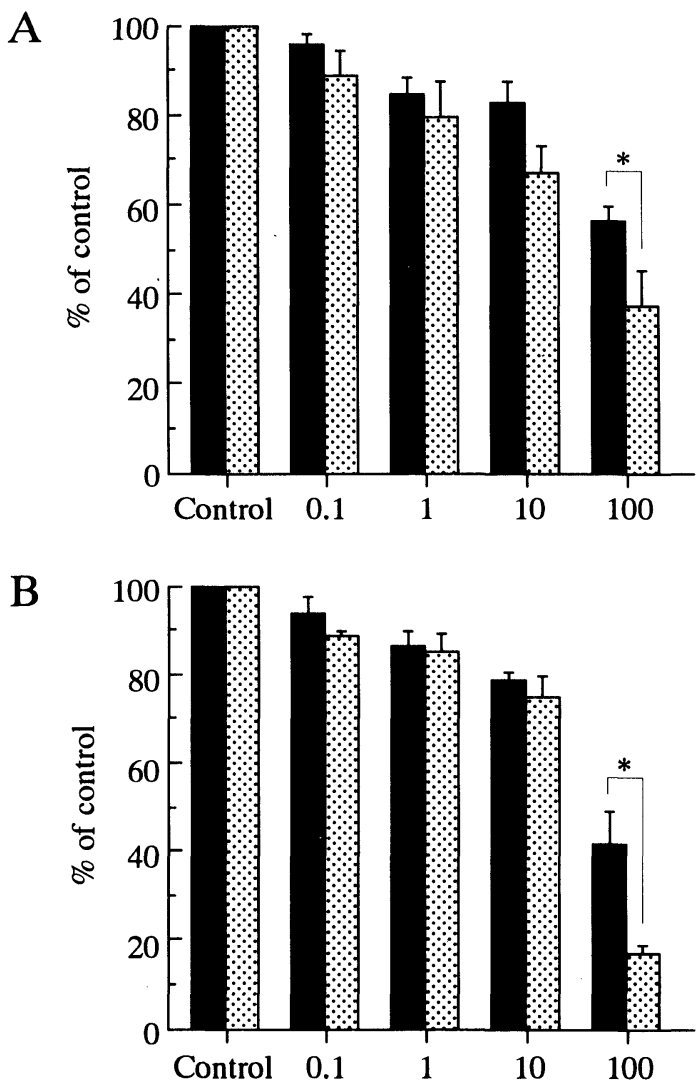

Concentrations of VP-16 (ng/ml)

Fig. 2. Relative cell counts of HL-60 and THP-1 cells after the treatment with VP-16. HL-60 (匹) or THP-1 (ङ) cells were incubated with or without VP-16 at various concentrations for 24 (A) or $48 \mathrm{hr}$ (B). Viable cells were counted by the trypan blue dye exclusion method at the end of culture. Viable cell counts of treated cells are indicated as the percent of untreated control cells. Each value represents the mean of 4 separate experiments. Bars represent S.E. ${ }^{*} p<0.05$ (HL-60 vs. THP-1 cells). 


\section{Results}

Effects of VP-16 on the cell cycle of HL-60 and THP-1 cells. VP-16 inhibited the proliferation of HL-60 and THP-1 cells at 24 and $48 \mathrm{hr}$ in a dosedependent manner (Fig. 2). Inhibition of the proliferation was stronger in THP- 1 than HL-60 cells at 24 and $48 \mathrm{hr}$ (significant at $100 \mathrm{ng} / \mathrm{ml}$ at both 24 and $48 \mathrm{hr} ; p<0.05, p<0.05$, respectively) (Fig. 2).

Representative flow cytograms of HL-60 and THP-1 cells treated with VP-16 at a concentration of $100 \mathrm{ng} / \mathrm{ml}$ for $24 \mathrm{hr}$ are shown in Fig. 3. VP-16 caused $\mathrm{G}_{2}$ block in the cell cycle of both cells. The cell cycle of each cell at $24 \mathrm{hr}$ is shown in Fig. 4. The number indicates the percentage of cells in each phase of the cell cycle. In HL-60 cells, VP- 16 caused relative increase in the $\mathrm{G}_{2} / \mathrm{M}$ phase cells at $100 \mathrm{ng} / \mathrm{ml}$, and also caused reduction in the $G_{0} / G_{1}$ and early $S$ phase cells at the

A

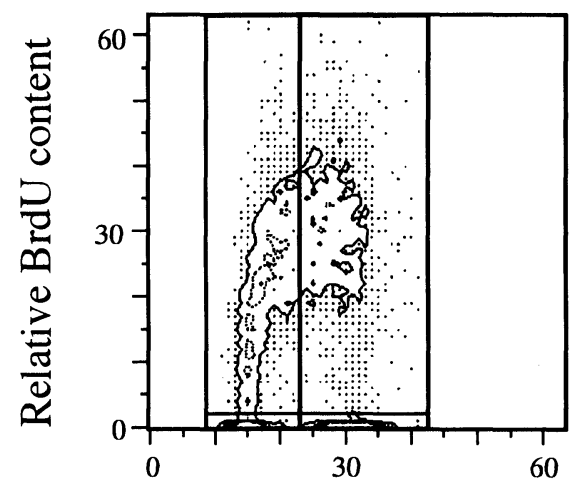

B

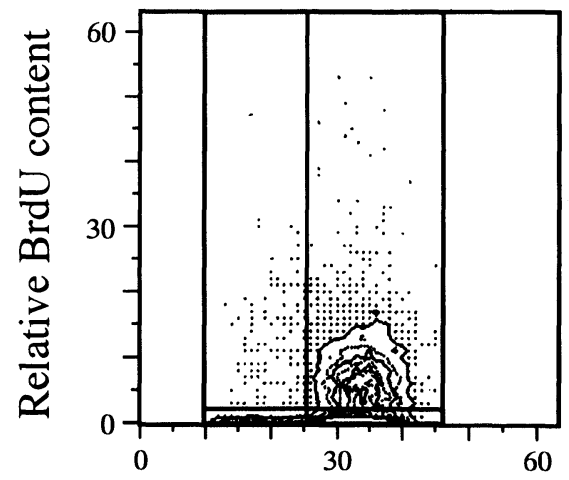

Relative DNA content

Fig. 3. Bivariate BrdU/DNA distributions of HL-60 and THP-1 cells after the treatment with VP-16. Representative flow cytograms of HL-60 (A) and THP-1 cells (B) treated with VP-16 at a concentration of $100 \mathrm{ng} / \mathrm{ml}$ for $24 \mathrm{hr}$ are shown. 

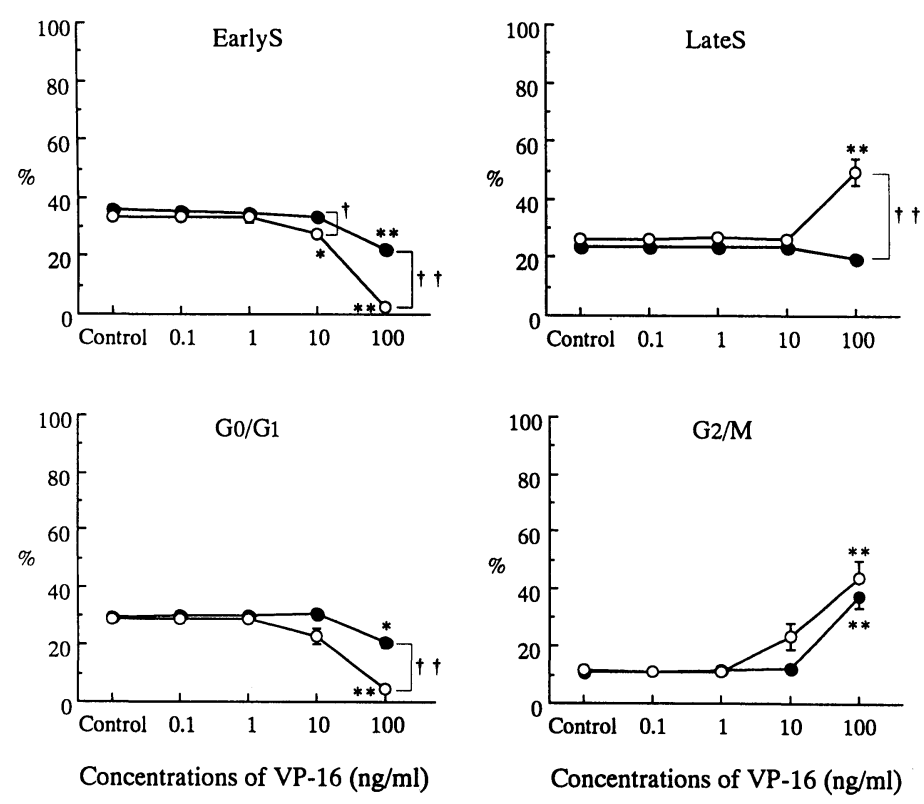

Fig. 4. Cell cycle of HL-60 and THP-1 cells after the treatment with VP-16 for $24 \mathrm{hr}$. HL-60 (•) or THP-1 cells (O) were incubated with or without VP-16 at various concentrations for $24 \mathrm{hr}$. Relative cell counts of treated and untreated cells in each phase of the cell cycle at $24 \mathrm{hr}$ were analyzed by flow cytometry using the anti-BrdU/DNA assay technique. Each value represents the mean and s.e. of 4 separate experiments. ${ }^{*} p<0.05$ (treated vs. untreated cells) $;{ }^{* *} p<0.01 ; \dagger p<0.05$ (HL-60 vs. THP-1 cells) ; $\dagger p<0.01$.

same concentration. In THP-1 cells, relative increase in the $\mathrm{G}_{2} / \mathrm{M}$ phase cells was observed at 10 and $100 \mathrm{ng} / \mathrm{ml}$, which was more marked than in HL-60 cells (although there were no significant differences). Reduction in the $G_{0} / G_{1}$ and early $\mathrm{S}$ phase cells was also detected at 10 and $100 \mathrm{ng} / \mathrm{ml}$, and was more marked in THP-1 than HL-60 cells (significant in the $\mathrm{G}_{0} / \mathrm{G}_{1}$ phase cells at $100 \mathrm{ng} / \mathrm{ml}, p<$ 0.01 ; the early $\mathrm{S}$ phase cells at $10 \mathrm{ng} / \mathrm{ml}$ and $100 \mathrm{ng} / \mathrm{ml}, p<0.05, p<0.01$, respectively). Relative increase in the late $S$ phase cells was observed at $100 \mathrm{ng} / \mathrm{ml}$ in THP-1 cells only. In the cell cycle at $48 \mathrm{hr}$ (Fig. 5), relative increase in the $\mathrm{G}_{2} /$ $\mathrm{M}$ phase cells was detected at 10 or $100 \mathrm{ng} / \mathrm{ml}$ in both cells, but there were no significant differences in the percentage of the $\mathrm{G}_{2} / \mathrm{M}$ phase cells between both cells. Reduction in the early and late $\mathrm{S}$ phase cells at $100 \mathrm{ng} / \mathrm{ml}$ was more marked in THP-1 than HL-60 cells (significant in the early $\mathrm{S}$ phase cells, $p<0.01$; the late $\mathrm{S}$ phase cells, $p<0.05$ )

Effects of Ara-C on the cell cycle of HL-60 and THP-1 cells. Ara-C inhibited the proliferation of HL-60 and THP-1 cells in a dose-dependent manner, as noted for VP-16 (Fig. 6). At $24 \mathrm{hr}$, Ara-C inhibited the proliferation of HL-60 more than THP-1 cells at 1 and $10 \mathrm{ng} / \mathrm{ml}(p<0.05, p<0.05$, respectively) (Fig. 6-A). At $48 \mathrm{hr}$, cell proliferation was inhibited more in THP-1 than HL-60 cells 

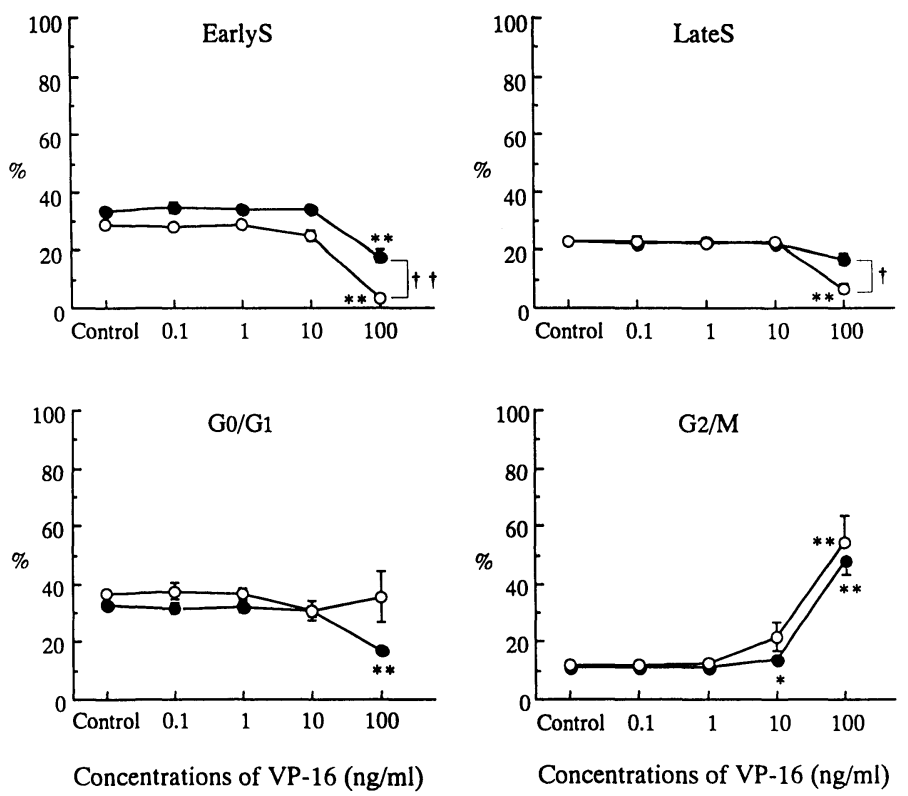

Fig. 5. Cell cycle of HL-60 and THP-1 cells after the treatment with VP-16 for $48 \mathrm{hr}$. HL-60 (๑) or THP-1 cells (O) were incubated with or without VP-16 at various concentrations for $48 \mathrm{hr}$. Relative cell counts of treated and untreated cells in each phase of the cell cycle at $48 \mathrm{hr}$ were analyzed by flow cytometry using the anti-BrdU/DNA assay technique. Each value represents the mean and s.E. of 4 separate experiments. ${ }^{*} p<0.05$ (treated vs. untreated cells) ; ${ }^{* *} p<0.01 ; \dagger p<0.05$ (HL-60 vs. THP-1 cells) ; † $p<0.01$.

at $0.1 \mathrm{ng} / \mathrm{ml}(p<0.05)$, in HL-60 than THP-1 cells at $10 \mathrm{ng} / \mathrm{ml}(p<0.05)$ (Fig. 6-B).

Representative flow cytograms of HL-60 and THP-1 cells treated with Ara-C at a concentration of $100 \mathrm{ng} / \mathrm{ml}$ for $24 \mathrm{hr}$ are shown in Fig. 7 . In the cell cycle at $24 \mathrm{hr}$ (Fig. 8), Ara-C caused relative increase in the early $\mathrm{S}$ phase cells and reduction in the $G_{0} / G_{1}$ phase cells at $10 \mathrm{ng} / \mathrm{ml}$ in HL-60 cells, but not in THP-1 cells (significant in the early $\mathrm{S}$ and $\mathrm{G}_{0} / \mathrm{G}_{1}$ phase cells: $p<0.05, p<0.05$, respectively). On the other hand, reduction in the early and late $\mathrm{S}$ phase cells and relative increase in the $G_{0} / G_{1}$ phase cells were observed in HL-60 cells at $100 \mathrm{ng} /$ $\mathrm{ml}$, although relative increase in the early $\mathrm{S}$ phase cells and reduction in the $\mathrm{G}_{0} /$ $G_{1}$ phase cells were still seen in THP-1 cells at the same concentration (significant in the $\mathrm{G}_{0} / \mathrm{G}_{1}$ phase cells, $p<0.01$; the early and late $\mathrm{S}$ phase cells, $p<0.01, p<$ 0.01 , respectively). In the cell cycle of $48 \mathrm{hr}$ (Fig. 9), relative increase in the early $\mathrm{S}$ phase cells was observed at 1 and $10 \mathrm{ng} / \mathrm{ml}$ in HL-60 cells only. Reduction in the $\mathrm{G}_{0} / \mathrm{G}_{1}$ phase cells was observed at the same concentrations in both of the cells and was more marked in HL-60 than THP-1 cells. Relative increase in the $G_{0} / G_{1}$ phase cells at $100 \mathrm{ng} / \mathrm{ml}$ was also observed in HL-60 cells only. 


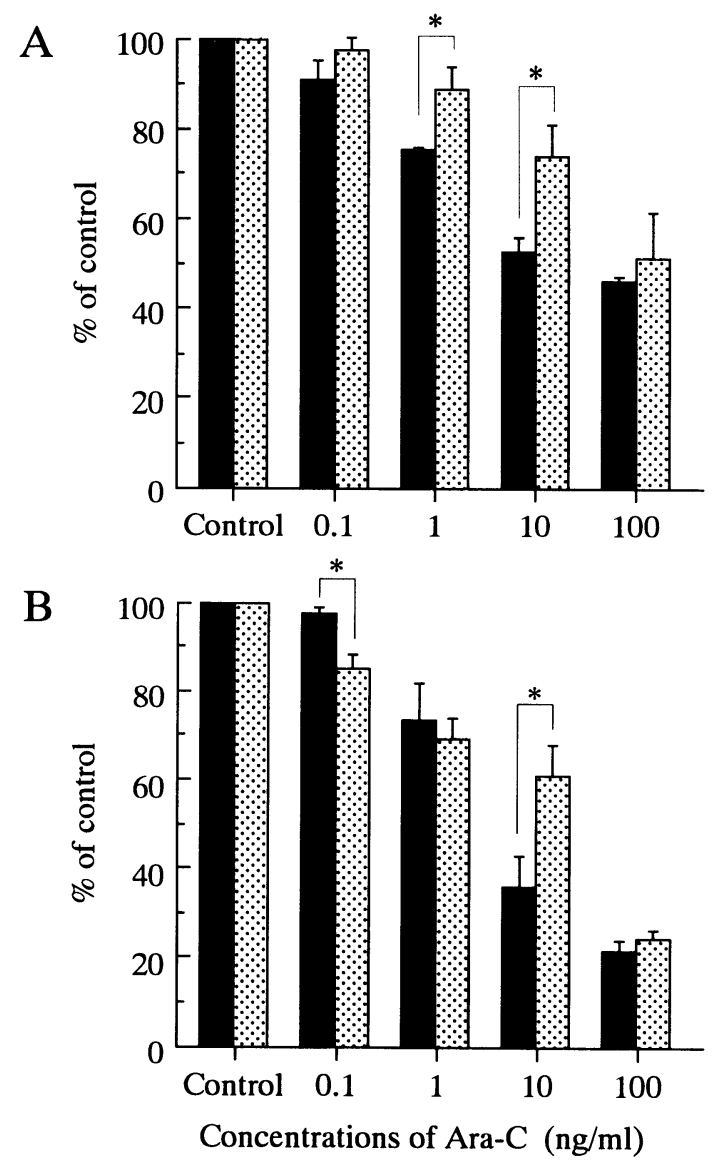

Fig. 6. Relative cell conuts of HL-60 and THP-1 cells after the treatment with Ara-C. HL-60 (ם) or THP-1 (छ) cells were incubated with or without Ara-C at various concentrations for 24 (A) or $48 \mathrm{hr}$ (B). Viable cells were counted by the trypan blue dye exclusion method at the end of culture. Viable cell counts of treated cells are indicated as the percent of untreated cells. Each value represents the mean of 4 separate experiments. Bars represent s.E. ${ }^{*} p<0.05$ (HL-60 vs. THP-1 cells).

\section{Discussion}

VP-16 is a recently developed anticancer agent belonging to the DNA topoisomerase II inhibitor and exerts strong antileukemic activity by inhibiting the synthesis of DNA in the S phase cells and inducing single-stranded breaks of DNA (Loike and Horwitz 1976; Roberts et al. 1980). In the analysis of the cell cycle by PI staining, VP-16 arrests leukemic cells in the $\mathrm{G}_{2}$ phase (Krishan et al. 1975). The mechanism of the $G_{2}$ block by VP-16 is considered to be as follows: cells whose DNA has been damaged in the $\mathrm{S}$ phase by VP-16 pass in some manner through the $S$ phase, but need much more time in the $G_{2}$ phase to repair the 
A

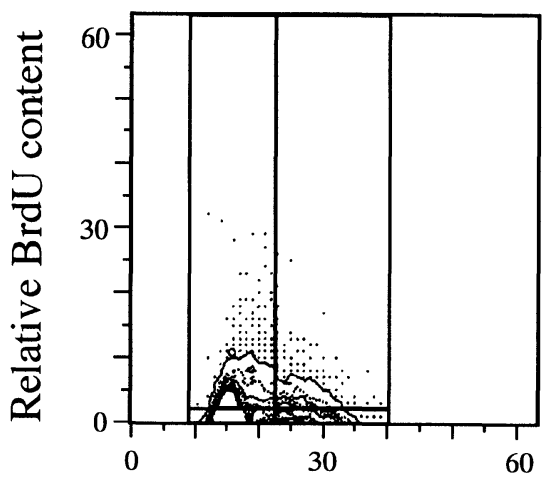

B

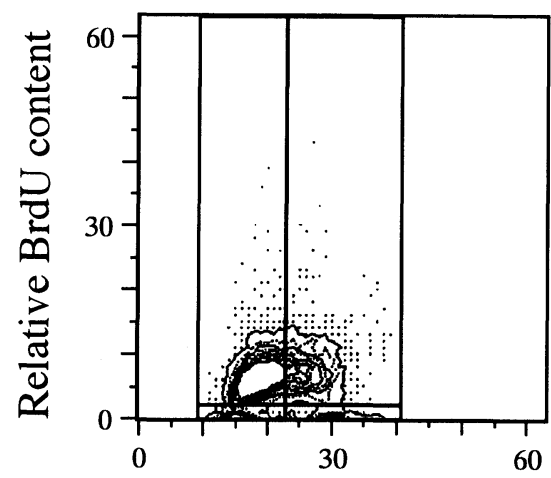

\section{Relative DNA content}

Fig. 7. Bivariate BrdU/DNA distributions of HL-60 and THP-1 cells after the treatment with Ara-C. Representative flow cytograms of HL-60 (A) and THP-1 cells (B) treated with VP-16 at a concentration of $100 \mathrm{ng} / \mathrm{ml}$ for $24 \mathrm{hr}$ are shown.

damaged DNA (Charcosset 1986). In this study, relative increase in the $\mathrm{G}_{2} / \mathrm{M}$ phase cells was observed by the treatment with VP-16 with the concentration of $100 \mathrm{ng} / \mathrm{ml}$ in THP-1 and HL-60 cells. Since the plasma level of VP-16 obtained from a patient treated with a standard dose therapy of this drug is about 1 to 10 $\mathrm{mg} / \mathrm{ml}$ (Wakui et al. 1986), the perturbation of the cell cycle could be revealed by VP-16 of much lower concentrations than those obtained by clinical doses. There were no significant differences in relative increase in the $\mathrm{G}_{2} / \mathrm{M}$ phase cells between both of the cells, but reduction in the $G_{0} / G_{1}$ and early $S$ phase cells was more marked in THP-1 than HL-60 cells. So the perturbation of the cell cycle by VP-16 was more remarkable in THP-1 than HL-60 cells. VP-16 also inhibited the proliferation of THP-1 cells more strongly than that of HL-60 cells at the same concentrations. According to these observations, the effects of VP-16 on the cell cycle would be more intense in THP-1 than HL-60 cells. These results are 

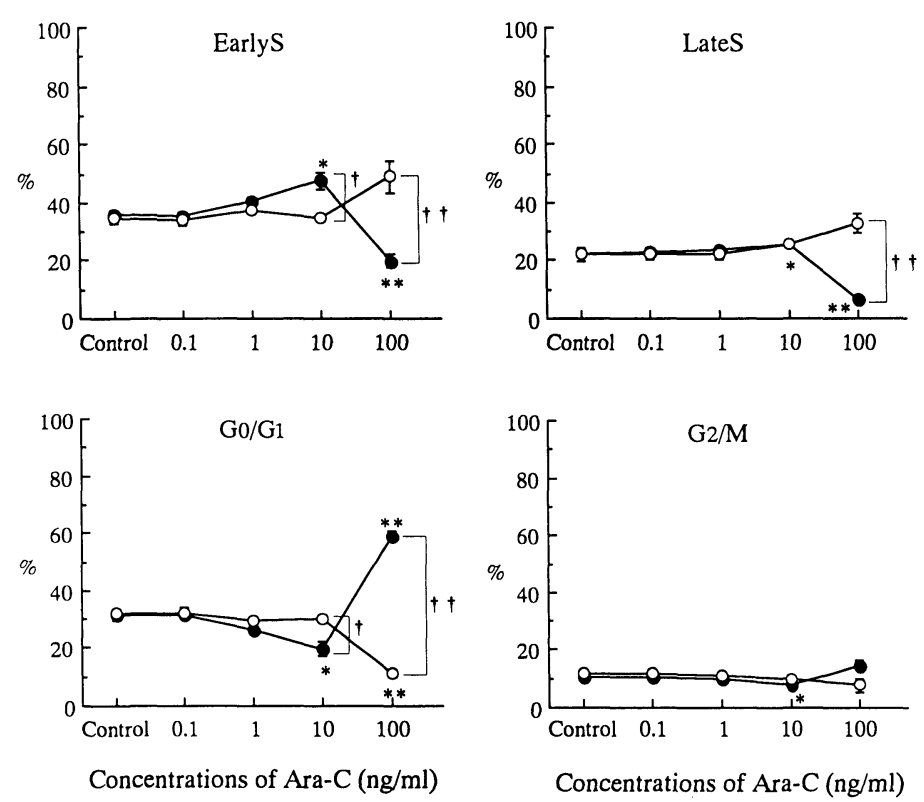

Fig. 8. Cell cycle of HL-60 and THP-1 cells after the treatment with Ara-C for 24 hr. HL-60 (•) or THP-1 cells (O) were incubated with or without Ara-C at various concentrations for $24 \mathrm{hr}$. Relative cell counts of treated and untreated cells in each phase of the cell cycle at $24 \mathrm{hr}$ were analyzed by flow cytometry using the anti-BrdU/DNA assay technique. Each value represents the mean and s.E. of 4 separate experinents. ${ }^{*} p<0.05$ (treated vs. untreated cells); ${ }^{* *} p<0.01 ; \dagger p<0.05$ (HL-60 vs. THP-1 cells); $\dagger p<0.01$.

compatible with the finding that VP-16 is more effective for patients with monocytic leukemia than for those with other types of leukemia (Mathé et al. 1974; Bernasconi et al. 1982; Varini and Cavalli 1982; Odom and Gordon 1984; Moriyama et al. 1985). The present in vitro data would support the efficacy of VP-16 for treating monocytic leukemia in vivo.

Ara-C is a type of antimetabolite agent and the key drug for treating acute non-lymphocytic leukemia. Its effect is specific for cells in the S phase. Analysis of the cell cycle has shown Ara-C to cause $\mathrm{S}$ delay at lower concentrations and $\mathrm{G}_{1}-\mathrm{S}$ block at higher concentrations (Charcosset 1986). In this study, Ara-C arrested HL-60 cells in the early S phase at lower concentrations ( 1 and $10 \mathrm{ng} / \mathrm{ml}$ ). The peak plasma concentration obtained from a patient after subcutaneous injection of low dose Ara-C is about 50 to $100 \mathrm{ng} / \mathrm{ml}$ (Ishikura et al. 1984), and the plasma concentration obtained by continuous infusion of standard dose Ara-C is about 10 to $100 \mathrm{ng} / \mathrm{ml}$ (Hirschmann et al. 1968). So the perturbation of the cell cycle by Ara-C revealed at much lower concentrations than those obtained by clinical doses. Ara-C arrested HL- 60 cells in the $\mathrm{G}_{0} / \mathrm{G}_{1}$ phase at higher concentration $(100 \mathrm{ng} / \mathrm{ml})$, which could be obtained by a standard or high dose therapy of Ara-C (Hirschmann et al. 1968; Urabe et al. 1985). Relative increase in the early 

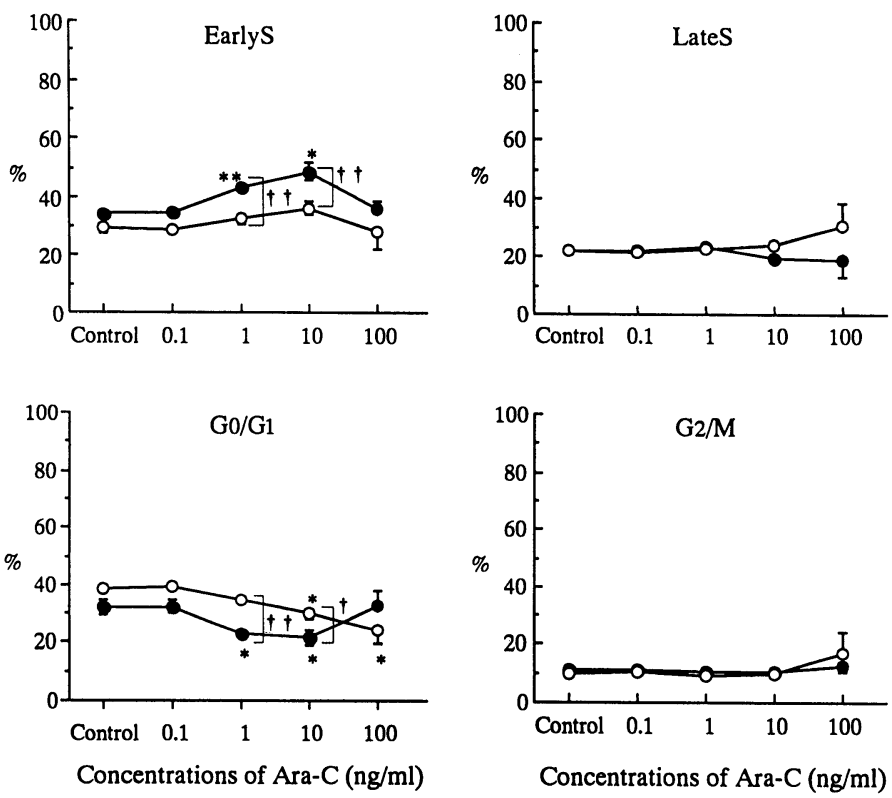

Fig. 9. Cell cycle of HL-60 and THP-1 cells after the treatmnt with Ara-C for 48 hr. HL-60 (๑) or THP-1 cells (O) were incubated with or without Ara-C at various concentrations for $48 \mathrm{hr}$. Relative cell counts of treated and untreated cells in each phase of the cell cycle at $48 \mathrm{hr}$ were analyzed by flow cytometry using the anti-BrdU/DNA assay technique. Each value represents the mean and s.e. of 4 separate experiments. ${ }^{*} p<0.05$ (treated vs. untreated cells); ${ }^{* *} p<0.01 ; \dagger p<0.05$ (HL-60 vs. THP-1 cells); †† $p<0.01$.

S phase cells and reduction in the $G_{0} / G_{1}$ phase cells at lower concentration was more marked in HL-60 than THP- 1 cells. Relative increase in the $G_{0} / G_{1}$ phase cells at higher concentration was observed in HL-60 cells only. Ara-C may thus be more effective for HL-60 than THP-1 cells in vitro. But there is no correlation between the cell cycle perturbation and the growth inhibition, so the specificity of Ara-C for cell type is not so great as that of VP-16.

The present results could not provide general conclusions because only one type of monocytic leukemia cells was examined, but they would indicate that VP-16 is effective particularly for monocytic leukemia in vitro as well as in vivo. Since flow cytometric analysis of the cell cycle by the BrdU/DNA assay technique could detect differences of the perturbation of the cell cycle by antileukemic agents between both of the cells, it may be useful for a chemosensitivity test of antileukemic agents. We are examining further on leukemic cells from clinical patients.

\section{References}

1) Bernasconi, C., Lazzarino, M., Morra, E., Salvaneschi, L., Canevari, A., Castelli, G., Brusamolino, E., Alessandrino, E. P., Isernia, P., Pagnucco, G. \& Orlandi, E. (1982) 
Etoposide (VP-16-213) in the treatment of acute monocytic and myelomonocytic leukemias. Chemioterapia, 1, 181-185.

2) Bettelheim, P., Valent, P., Andreeff, M., Tafuri, A., Haimi, J., Gorischek, C., Muhm, M., Sillaber, C., Haas, O., Vieder, L., Maurer, D., Schulz, G., Speiser,W., Geissler, K., Kier, P., Hinterberger, W. \& Lechner, K. (1991) Recombinant human granulocytemacrophage colony stimulating factor in combination with standard induction chemotherapy in de novo acute myeloid leukemia. Blood, 77, 700-711.

3) Bishop, J.F., Lowenthal, R.M., Joshua, D., Matthews, J.P., Todd, D., Cobcroft, R., Whiteside, M.G., Kronenberg, H., Ma, D., Dodds, A., Herrmann, R., Szer, J., Wolf, M.M. \& Young, G. (1990) Etoposide in acute non-lymphocytic leukemia. Blood, 75, $27-32$.

4) Charcosset, J.Y. (1986) Effects of antineoplastic agents on the cell cycle progression. Biol. Cell, 58, 135-138.

5) Collins, S.J., Gallo, R.C. \& Gallagher, R.E. (1977) Continuous growth and differentiation of human myeloid leukaemic cells in suspension culture. Nature, 270, 347-349.

6) Dolbeare, F., Gratzner, H., Pallavicini, M.G. \& Gray, J.W. (1983) Flow cytometric measurement of total DNA content and incorporated bromodeoxyuridine. Proc. Natl. Acad. Sci. USA, 80, 5573-5577.

7) Gratzner, H.G. (1982) Monoclonal antibody to 5-Bromo- and 5-iododeoxyuridine: A new reagent for detection of DNA replication. Science, 218, 474-475.

8) Hirschmann, W.D., Kovacs, E.L., Gerecke, D., Kaulen, H.-D., Voigtmann, R. \& Gross, R. (1968) Zur Applikationsweise und Inaktivierung von Cytosin-Arabinosid bei akuten Leukaemien. Verh. Dtsch. Ges. Inn. Med., 81, 1114-1116.

9) Ishikura, H., Sawada, H., Okazaki, T., Mochizuki, T., Izumi, Y., Yamagishi, M. \& Uchino, H. (1984) The effect of low dose Ara-C in acute non-lymphoblastic leukaemias and atypical leukaemia. Br. J. Haematol., 58, 9-18.

10) Katano, N., Tsurusawa, M., Niwa, M. \& Fujimoto, T. (1989) Flow cytometric determination with bromodeoxyuridine/DNA assay of sensitivity of S-phase cells to cytosine arabinoside in childhood acute lymphoblastic leukemia. Am. J. Pediatr. Hematol. Oncol., 11, 411-416.

11) Krishan, A., Paika, K. \& Frei, E. (1975) Cytofluorometric studies on the action of podophyllotoxin and epipodophyllotoxins (VM-26, VP-16-213) on the cell cycle transverse of human lymphoblasts. J. Cell Biol., 66, 521-530.

12) Loike, J.D. \& Horwitz, S.B. (1976) Effect of VP-16-213 on the intracellular degradation of DNA in HeLa cells. Biochemistry, 15, 5435-5443.

13) Mathé, G., Schwarzenberg, L., Pouillart, P., Oldham, R., Weiner, R., Jasmin, C., Rosenfeld, C., Hayat, M., Misset, J.L., Musset, M., Schneider, M., Amiel, J.L. \& De Vassal, F. (1974) Two epipodophyllotoxin derivatives, VM-26 and VP-16-213, in the treatment of leukemias, hematosarcomas, and lymphomas. Cancer, 34, 985-992.

14) Moriyama, Y., Shibata, A., Maekawa, I., Yoshida, Y., Miura, A., Wakui, A., Kariyone, S., Maekawa, T., Miura, Y., Abe, T., Furusawa, S., Nomura, T., Takaku, F., Urabe, A., Miwa, S., Toyama, K., Mizoguchi, H., Osamura, S., Nakao, I., Terada, H., Shirakawa, S., Nakamura, T., Uchino, H., Kitani, T., Tagawa, S., Horiuchi, A., Masaoka, T., Yasunaga, K., Kawagoe, H., Yonezawa, T., Okuda, K., Nagai, K. \& Kohsaki, M. (1985) A phase II trial of etoposide (VP-16) administrated intravenously in the treatment of malignant lymphoma and acute leukemia. Jpn. J. Clin. Hematol., 26, 1774-1784. (in Japanese)

15) Odom, L.F. \& Gordon, E.M. (1984) Acute monoblastic leukemia in infancy and early childhood: Successful treatment with an epipodophyllotoxin. Blood, 64, 875882.

16) Roberts, D., Hilliard, S. \& Peck, C. (1980) Sedimentation of DNA from L1210 cells after treatment with $4^{\prime}$-demethylepipodophyllotoxin-9-(4, 6-O-2-thenylidene- $\beta$-D- 
glucopyranoside) or 1- $\beta$-D-arabinofuranosyl-cytosine or both drugs. Cancer Res., 40, 4225-4231.

17) Tafuri, A. \& Andreeff, M. (1990) Kinetic rationale for cytokine-induced recruitment of myeloblastic leukemia followed by cycle-specific chemotherapy in vitro. Leukemia, 4, 826-834.

18) Tsuchiya, S., Yamabe, M., Yamaguchi, Y., Kobayashi, Y., Konno, T. \& Tada, K. (1980) Establishment and characterization of a human acute monocytic leukemia cell line (THP-1). Int. J. Cancer, 26, 171-176.

19) Urabe, A., Takaku, F., Mizoguchi, H., Yamada, O., Wakabayashi, Y., Miura, Y., Sakamoto, S., Yoshida, M., Miwa, S., Asano, S., Morisaki, T., Nomura, T., Toyama, K., Aoki, I., Murase, T., Maekawa, T., Miyawaki, S., Murakami, H., Yamada, H., Ohno, R., Kawashima, K., Yokomaku, S., Kinugasa, K., Adachi, Y., Mori, M.,Ise, T., Mutoh, Y. \& Yamaguchi, H. (1985) High-dose cytosine arabinoside in acute leukemia: A cooperative study. Jpn. J. Clin. Hematol., 26, 184-188. (in Japanese)

20) Varini, M. \& Cavalli, F. (1982) Etoposide in the treatment of acute leukemia in adults. Cancer Treat. Rev., 9 Suppl. A, 59-62.

21) Wakui, A., Yokoyama, M., Takahashi, H., Yoshida, Y., Sakata, Y., Sato, S., Kano, A., Kawamoto, K., Hashimoto, S., Konno, K., Koinumaru, S., Nakai, Y., Masamune, O., Inoue, Y., Miura, A., Akihama, T., Suzuki, K., Numasawa, K., Endo, S., Watanabe, I., Suzuki, M., Saito, T. \& Nakao, I. (1986) A phase I study of VP-16-213 (Etoposide) by a single and 5-day intravenous administration. Jpn. J. Cancer Chemother., 13, $319-329$. 